\title{
Jazz Chants in English Language Teaching*
}

\author{
Jin Zhang \\ Chuzhou University, Chuzhou, China \\ Email: angelica_zj@yahoo.com.cn
}

\begin{abstract}
In this paper, we introduce the theoretical background of Jazz Chants and its definition, and then discuss the application of Jazz Chants in English Language Teaching, esp. the methods, including the definition of Jazz Chants, the methods which could be applied in the teaching, how to teach different chants to the students in different ages, and its effects in language acquisition.
\end{abstract}

Index Terms - Jazz chants, English language teaching, content-based instruction, rhythm, SLA

\section{CONTENT AND LANGUAGE INTEGRATED LEARNING}

Content and Language Integrated Learning (CLIL) has become the umbrella term describing both learning another (content) subject such as physics or geography through the medium of a foreign language and learning a foreign language by studying a content-based subject. In ELT, forms of CLIL have previously been known as Content-based instruction, English across the curriculum' and Bilingual education. These cross-curricular teaching methods could be in my opinion easily applied also to learning English through Music and vice versa learning Music through English which will be clear from the practical part of this work.

CLIL helps to: Introduce the wider cultural context; Prepare for internationalization Access International Certification and enhance the school profile; Improve overall and specific language competence; Prepare for future studies or working life Develop multilingual interests and attitudes; Diversify methods \& forms of classroom teaching and learning; Increase learner motivation.

In the old course books there was paid very little attention to such additional materials like songs. Only now and then learners could find some largely known songs such as Jingle Bells or Oh, Christmas Tree.

Nowadays the situation with the textbooks is better although in my opinion not as good as it could be. There are songs usually connected to some special events or holidays (Christmas, Easter, and Valentine's Day) included in the books but children are often eager to sing and they cannot repeat the same song over and over all the time. Therefore there is a considerable need for more singing material in the English course books.

\section{MUSIC IN ENGLISH LESSONS}

Learning English as a foreign language is supported by Krashen's hypotheses as well. According to the first one, listening to songs along with the usage of pictures, photos or gestures is conformable to orally-read stories supported by different visual materials, which finally in both cases leads to language acquisition. In accordance with the second hypothesis, the Affective Filter hypothesis, the extent to which linguistic input is received from the environment depends mostly upon the learner's inner feelings and attitude. It means that if a learner is unmotivated or has little confidence, language acquisition will be limited and therefore the teacher must provide an environment with positive emotions. Music creates exactly this needed situation. Furthermore, it develops a sense of community and all that together brings about language acquisition.

There are many different types of music and teachers have to choose carefully the songs they want to use for their target group of children. What should be taken into consideration is mainly age of students, their level of English and interests.

As to the learners' age, the youngest children usually appreciate simple songs with many repetitions which are full of concrete nouns and verbs being easy to imagine and close to their range of vocabulary in their mother tongue. They like to see pictures or some objects while singing the songs, mainly during the learning stage, and they often love songs with possible movements (Head and Shoulders). The song lyrics for kindergarten and lower primary learners should have simple pronunciation and children should be able to acquire them quickly and naturally. Songs for older and more advanced students could be of course more difficult in pronunciation and the type of vocabulary but here very close attention must be paid to pupils' interests because if a chosen song is too childish or on the other hand too difficult as to its vocabulary, grammar structures or to its content, learners can feel ridiculous or confused and that would probably lead to motivation decrease and some kind of a lock up in their further learning.

\section{JAZZ CHANTS}

\footnotetext{
* The paper is supported by Chuzhou University, and the teaching research project ID is 2008jy013.
} 
Carolyn Graham claims (2006) Jazz Chant is a rhythmic expression of natural language which links the rhythms of spoken American English to the rhythms of traditional American jazz. The rhythms, stress and intonation pattern of the chant should be an exact replica of what the student would hear from an educated native speaker in natural conversation.

Carolyn Graham discovered Jazz Chants only by accident while playing the piano in one bar. Her friend came to her said several words in which she could feel exactly the music beat she was playing. That way she found the connection between traditional American jazz and spoken American English.

The music for chants is often taken from some traditional English songs so the children can concentrate on the words and rhythm more because they already know the melody from the original songs, for instance melodies from Twinkle, Twinkle Little Star or Are You Sleeping. (Graham, 2006)

There are many types of Jazz Chants depending on what the teacher wants to practice. They can be divided into two main groups: topic Jazz Chants and grammar/structure Jazz Chants. The topic Jazz Chants are always connected to some specific theme such as holidays, family, nature, seasons, animals, food, transport, health, occupations, hobbies, days of the week etc., whereas the role of grammar/structure Jazz Chants is to teach or practise some English grammar or structure such as: different verbs, prepositions, tenses, questions, answers, imperatives, structures like there is/are, to be going to, or for example pronouns.

There is one more group and that is when the two mentioned types are combined together but that could be done by teachers themselves too and it does not have to be a specific Jazz Chant.

There are many methods how to use the chants for teaching English as a foreign language and probably one of the best ones is suggested by Carolyn Graham in her books with Jazz Chants.

\section{A. Method by Carolyn Graham}

STEP 1: Preview: Talking about the title of the chant, what the students think it is about, explain connection to cultural context. With young learners using about their mother tongue, with older ones simple English can be used. STEP 2: Listen: Familiarizing students with the chant, singing it or playing on a CD player, stressing the rhythm of the chant by using different rhythmic instruments (drums, tambourines or just hands, pencils or feet); STEP 3: Choral chanting: Students open their books or teacher writes the text of the chant on the blackboard so they can read it and repeat it after the teacher or recording. If the students have some difficulty to pronounce individual words or phrases, teacher can isolate them from the rest of the text and practice it with learners only with some small chunk of the text. STEP 4: Group/ individual chanting: First of all students try the chant as a whole class, then the teacher can divide them into several groups in order to practice different parts of it (for example questions and answers). Students can also pantomime or act the chants out while singing. Then children may get into pairs and sing and chants for the class in turns. After the students know the chants by heart an excellent method how to acquire naturally the language is to personalize it. This could be done in many ways. For instance substitutions (names, places, pronouns) and along with the substitution changing grammar structures (the 1st person changed into the 3rd person). Another possible method is role playing or moving the chant language into situational context. Finally, the teacher can create variety of exercises which would follow what the students have learned. (Graham, 2001)

\section{B. Why to Use Jazz Chants}

Jazz Chants considerably improve students' listening and speaking skills. This is probably the most important point. They practice stress and rhythm, are highly motivating and encourage role playing and pair activities. They strengthen language structures and the ability to speak every day spoken English. Chants are simple, provide the language children really use and are repetitive, which, mainly in case of very young learners, is quite necessary. They are suitable for all ages, teachers must only choose the right accompanying activities. They help students to remember difficult words or phrases. And last but not least, children are themselves while singing, clapping or shouting. (Loutfi, n.d.)

\section{Who to Use Jazz Chants with}

Chants are suitable for all students no matter what age they are and what level of English, learning strategies, intelligence, interests or learning problems they have. However, in my opinion, chant activities are best for children with some kind of disabilities whether they are learning, behavioural or health.

In case of the learning disabilities (dyslexia, dysgraphia, disorthographia) it could be a good way how to make them remember and understand for example vocabulary, which is usually the biggest problem together with pronunciation and rhythm of the English language and spelling. Regarding students with behavioural problems, here I would consider it as a solution because with all that clapping, jumping, hitting things and singing and often also creating objects they do not have time to be disturbing. And if a teacher has in his or her class some integrated students (for example sightless or physically or mentally handicapped) he or she can use chants to lead them in and to incorporate them into the class.

\section{Teachers and Learners can Make Their Own Jazz Chants}

Very motivating and interesting method is making teachers' or students' own chants. Here the process would be as follows: try several "ready-made" chants and use several different methods while working with them: take a text of some chant and try to adjust it according to your own imagination; try some methods on the adjusted chant and see if 
others like it; think of an area (vocabulary, grammar, set expressions...) for which you would like to make your chant and then write something short and simple and rhythmical; read it to others and see if they like it and if it is easy for them to follow you in vocabulary and rhythm; if yes, you can start working with your new chant using any method and activity you like; DO NOT FORGET TO RECORD YOUR WORK SOMEHOW (write it into your exercise book, record it on a tape; for teachers: you can make a file with students' chants and use it for your portfolio.

\section{CONCLUSION}

The aim of my work was to stress the importance of different additional materials such as Jazz Chants and other chant related activities in English lessons mainly with very young and young students.

Listening and speaking are probably the most important skills a person needs to be able to communicate and also the first ones to be acquired either in learning the mother tongue or any foreign language. In order to reach a reasonable level of those competences it is very important to use variety of methods and some of the most suitable ones are chanting and singing. In my thesis I also stressed the significance of the Krashen's hypothesis about singing and listening to songs for foreign language acquiring and connection of Jazz Chants to CLIL, which is being highlighted these days in the new school programs.

Music, rhyming and chanting combine two necessary phenomena for learning a language: the system of language and pleasure. This does not apply only to foreign languages but also to the mother tongues. Children must enjoy learning and through chants it is not only possible but even highly likely. Here I would stress the role of motivation as well. Students, excepting only some individuals, are usually markedly inveigled by such activities to work more and harder.

My thesis includes both, some theoretical support based on the works of specialists in language learning such as Harmer, Graham, Byrne or Murphey and an entirely practical part with detailed lesson plans full of ideas how to use Jazz Chants for specific groups of students and I even created three chants by myself being inspired by Carolyn Graham's books.

Music and rhymes are very entertaining and children love them, nevertheless, I would not suggest using only singing and chanting to learn a foreign language. However, as an additional material it is a perfect method how to make children motivated and involved in language lessons, especially the little children, slower students or students with some learning difficulties. I strongly suppose that by using such activities incorporated into usual lessons a teacher can reach significantly better study and also behavioral results and it can be also seen on the DVD which is one of the appendices to this work.

\section{REFERENCES}

[1] Byrne, D. (1988). Focus on the Classroom. Oxford: Modern English Publications.

[2] Doff, A. (1993). Teach English: A training course for teacher. Cambridge: CUP.

[3] Graham, C. (2006). Creating Chants and Songs. Oxford: OUP.

[4] Graham, C. (1999). Holiday Jazz Chants. Oxford: OUP.

[5] Graham, C. (1979). Jazz Chants for Children. Oxford: OUP.

[6] Graham, C. (2001). Jazz Chants Old and New. Oxford: OUP.

[7] Harmer, J. (1994). The Practice of English Language Teaching. New York: Longman Group UK Limited.

[8] Murphey, T. (1992). Music and Songs. Oxford: OUP.

[9] O'Grady, W. (2005). How Children Learn Language. Cambridge: CUP.

[10] Phillips, S. (1993). Young Learners. Oxford: OUP.

[11] Skoumal, P., \& Votruba, J. (2000). Humpty Dumpty Mother Goose Songs and Rhymes and Other More Grown-up Songs and Christmas Carols. Praha: Angličtina Expres.

[12] Ur, P. (2000). A Course in Language Teaching (Practice and Theory). Cambridge: CUP.

[13] Wajnryb, R. (1992). Classroom Observation Tasks (A source book for language teachers and learners). Cambridge: CUP.

[14] Wright, A., Betteridge, D., \& Buckby, M. (1991). Games for Language Learning. Cambridge: CUP.

Jin Zhang was born in Chuzhou, China in 1980. She received his. degree in linguistics from Anhui Normal University, China in 2003.

She is currently a lecturer in the Foreign Languages department, Chuzhou University, Chuzhou, China. Her research interests include psycholinguistics and SLA. 